\title{
Spatial, temporal and size distribution of particulate matter and its chemical constituents in Faisalabad, Pakistan
}

\author{
WASIM JAVED \\ Mechanical Engineering, Texas A\&M University at Qatar, Doha, Qatar; \\ Institute of Soil and Environmental Sciences, University of Agriculture, Faisalabad, Pakistan \\ Corresponding author; e-mail: wasim.javed@qatar.tamu.edu \\ ANTHONY S. WEXLER \\ Air Quality Research Center, University of California-Davis, CA, USA \\ GHULAM MURTAZA and HAMAAD R. AHMAD \\ Institute of Soil and Environmental Sciences, University of Agriculture, Faisalabad, Pakistan \\ SHAHZAD M. A. BASRA \\ Department of Crop Physiology, University of Agriculture, Faisalabad-38040, Pakistan
}

Received May 25, 2014; accepted February 6, 2015

\begin{abstract}
RESUMEN
Se investigaron las variaciones espaciales y temporales de aerosoles de material particulado (PM, por sus siglas en inglés) en Faisalabad, Pakistán, de junio de 2012 a abril de 2013 para conocer la distribución de componentes químicos y fracciones granulométricas en todas las estaciones del año. Se controlaron cuatro fracciones de PM (partículas totales en suspensión [TSP, por sus siglas en inglés], $\mathrm{PM}_{10}, \mathrm{PM}_{4}$ y $\mathrm{PM}_{2.5}$ ) en nueve sitios de muestreo y de manera simultánea se colectaron muestras de TSP en filtros de fibra de vidrio utilizando un dispositivo de alto volumen para toma de muestras de aire. Las muestras de TSP (144) se sometieron a un análisis químico cuantitativo para determinar la presencia de elementos traza $(\mathrm{Pb}, \mathrm{Cd}, \mathrm{Ni}$, $\mathrm{Zn}, \mathrm{Cu}, \mathrm{Fe})$ mediante espectroscopia de absorción atómica, así como de cationes solubles en agua $\left(\mathrm{Ca}^{2+}\right.$, $\left.\mathrm{Mg}^{2+}, \mathrm{Na}^{+}, \mathrm{K}^{+}, \mathrm{NH}_{4}^{+}\right)$y aniones $\left(\mathrm{Cl}^{-}, \mathrm{SO}_{4}^{2-}\right.$ y $\left.\mathrm{NO}_{3}{ }^{-}\right)$por cromatografía iónica. Las mayores concentraciones de PM se observaron en sitios industriales; las concentraciones en cruces de vialidades principales fueron menores, y los valores más bajos se obtuvieron en un sitio remoto. Las concentraciones de PM fueron aproximadamente de dos a 20 veces mayores que los estándares establecidos por la Organización Mundial de la Salud y la Agencia de Protección Ambiental estadounidense. Las partículas gruesas (TSP y $\left.\mathrm{PM}_{10}\right)$ registraron mayores niveles durante el verano y las partículas relativamente pequeñas $\left(\mathrm{PM}_{4}\right.$ y $\left.\mathrm{PM}_{2.5}\right)$ durante el invierno, en tanto que las concentraciones de partículas de todos los tamaños fueron menores durante la época de monzones en todos los sitios. Las concentraciones de los diferentes elementos y iones solubles en agua siguieron un patrón estacional similar al de las concentraciones de PM. Los elementos de la corteza terrestre $\mathrm{Ca}, \mathrm{Fe}, \mathrm{Mg}$ y Na fueron los mayor contribuyentes a las TSP, en tanto que las concentraciones de origen antropogénico $(\mathrm{Pb}, \mathrm{Cd}, \mathrm{Ni}, \mathrm{Cu}$ y $\mathrm{Zn})$ fueron relativamente bajas y mostraron alta variabilidad espacial. El sulfato $\left(\mathrm{SO}_{4}{ }^{2-}\right)$ contribuyó con $50-60 \%$ de la concentración total de aniones y fue la especie predominante de éstos. Se encontró que la precipitación, la velocidad del viento y la humedad relativa fueron los factores meteorológicos que tuvieron mayor efecto sobre las concentraciones de PM. La evaluación de los datos presentados en este documento servirá como base para la modelación regional y la asignación de fuentes en el futuro.
\end{abstract}




\section{ABSTRACT}

Spatial and temporal variations in aerosol particulate matter (PM) were investigated for distribution over the four seasons of chemical constituents and particle size fractions in Faisalabad, Pakistan from June 2012 to April 2013. At nine sampling sites, four PM mass size fractions (total suspended particulates [TSP], $\mathrm{PM}_{10}$, $\mathrm{PM}_{4}$ and $\mathrm{PM}_{2.5}$ ) were monitored; simultaneously, TSP mass samples were collected on glass fiber filters using a high volume air sampler. TSP samples (144) were subjected to quantitative chemical analyses for determining trace elements $(\mathrm{Pb}, \mathrm{Cd}, \mathrm{Ni}, \mathrm{Zn}, \mathrm{Cu}, \mathrm{Fe})$ using atomic absorption spectroscopy, and water-soluble cations $\left(\mathrm{Ca}^{2+}, \mathrm{Mg}^{2+}, \mathrm{Na}^{+}, \mathrm{K}^{+}, \mathrm{NH}_{4}^{+}\right)$and anions $\left(\mathrm{Cl}^{-}, \mathrm{SO}_{4}{ }^{2-}\right.$ and $\left.\mathrm{NO}_{3}^{-}\right)$by ion chromatography. The highest PM mass concentrations were observed at industrial sites, while they were somewhat lower in major road intersections and lowest in the remote background site. It was also observed that PM mass concentrations were about two to 20 times higher than the standard limits of the World Health Organization and the US Environmental Protection Agency. Coarse particles (TSP, $\mathrm{PM}_{10}$ and $\mathrm{PM}_{4}$ ) were found to be highest during the summer, while relatively fine particles $\left(\mathrm{PM}_{2.5}\right)$ were higher during the winter period. Concentrations of all size fractions were lowest during the monsoon sampling period at all sites. Concentrations of different elements and water-soluble ions also followed the similar temporal pattern as PM mass concentrations. The crustal elements $\mathrm{Ca}, \mathrm{Fe}, \mathrm{Mg}$ and $\mathrm{Na}$ were the largest contributors to TSP mass while elements of anthropogenic origin $(\mathrm{Pb}, \mathrm{Cd}, \mathrm{Ni}, \mathrm{Cu}$ and $\mathrm{Zn})$ had relatively lower concentrations and also showed a high spatial variation. Among the anions, sulfate $\left(\mathrm{SO}_{4}{ }^{2-}\right)$ was the predominant species contributing to $50-60 \%$ of the total anion concentration. It was found that rainfall, wind speed and relative humidity were the most important meteorological factors affecting PM concentrations. The evaluation of data presented in this paper will serve as a basis for future regional modeling and source apportionment.

Keywords: TSP, $\mathrm{PM}_{10}, \mathrm{PM}_{2.5}$, size distribution, meteorology.

\section{Introduction}

Atmospheric degradation has become a severe threat to human health and welfare in developing countries like Pakistan, where urbanization, motorization, and industrialization coupled with concomitant growth of energy use are growing rapidly. This threat is especially severe in areas where technologies and strategies for controlling emissions are limited due to lax legislative standards and enforcement of regulations (Colbeck et al., 2010; Shah and Shaheen 2010; Shah et al., 2012).

Airborne particulate matter (PM) is ubiquitous in the atmosphere and is a major indicator of air quality in a given area. PM varies widely in size, concentration and chemical composition. It is regulated globally under permissible standards based on size fractions ranging from $\mathrm{PM}_{2.5}$ (respirable fine particles, aerodynamic diameter $\leq 2.5 \mu \mathrm{m}$ ) to $\mathrm{PM}_{10}$ (inhalable coarse particles, aerodynamic diameter $\leq 10 \mu \mathrm{m}$ ) to TSP (total suspended particles, aerodynamic diameter $\leq 100 \mu \mathrm{m}) . \mathrm{PM}_{4}$ (aerodynamic diameter $\leq 4 \mu \mathrm{m}$ ) is also known as the respirable size fraction (Mar et al., 2004). PM originates from a variety of natural (e.g., sea spray and dust storms), and anthropogenic (e.g., power plants, brick kilns, waste incineration, industrial emissions, motor vehicles, and agricultural activities) sources, as well as secondary formation processes.

The chemical composition of PM has also been widely explored because it can determine the impacts on visibility, climate change and consequent health risks, as well as its potential sources and formation processes (Ragosta et al., 2008). Hence, the assessment of atmospheric PM concentrations and its toxic constituents is a prerequisite for epidemiological studies and air quality management (Bhaskar et al., 2008; Shah et al., 2012).

Epidemiological studies have consistently confirmed a strong association between ambient PM containing toxic components and respiratory- and cardiovascular-related increases in morbidity and mortality, especially in urban areas (e.g., Pope 2000; Becker et al., 2005). This association has been revealed to be stronger for $\mathrm{PM}_{2.5}$ than for $\mathrm{PM}_{10}$ or TSP, since $\mathrm{PM}_{2.5}$ can penetrate deep into the alveolar region of the human lungs (Mar et al., 2004).

The distribution and transport of PM in the atmosphere is markedly associated with meteorological parameters such as wind speed and direction, relative humidity $(\mathrm{RH})$, rainfall, and temperature (Pakbin et al., 2010). Therefore, PM concentrations and meteorological data should be evaluated statistically in order to develop correlations that can assist in identifying sources and thereby assist in the design of cost-effective emissions control strategies. In the absence of measurements relative to other major air 
pollutants in this part of the world, PM and its associated chemical species can be a useful index of air quality, providing also indirect information on the presence of other (primary and secondary) pollutants (Ragosta et al., 2008).

Air pollution control in Pakistan has not yet become an electoral issue due to a lack of adequate information for decision and policy makers (Shah et al., 2012), although some sporadic reports that recognize airborne PM as a serious environmental and health concern in urban areas of Pakistan are available (Pak-EPA/JICA, 2001; Pak-EPA, 2005; Colbeck et al., 2010). In general, PM concentrations are many times higher than the World Health Organization (WHO) and the United States Environmental Protection Agency (US-EPA) permissible limits. According to the World Bank (2006), the annual health burden due to PM is $1 \%$ of the gross domestic product and is responsible for 22000 premature deaths among adults and 700 deaths among children in Pakistan.

The work presented here is based on the hypothesis that PM varies broadly (spatially and temporally) in size, concentration and chemical composition in the study area, Faisalabad, Pakistan, likely due to various sporadic local sources. The study was carried out to assess ambient PM concentrations and their chemical constituents during a one-year monitoring period and then to estimate different possible sources contributing to these concentrations based on mutual correlation patterns. This work could be used as an incentive to initiate other studies on trend analysis, impact assessment and source identification for this region. It is anticipated that the present study will be helpful for designing and instituting future abatement strategies and emissions regulations.

\section{Materials and methods}

\subsection{Study area}

Faisalabad $\left(73-74^{\circ} \mathrm{E}, 30-31.15^{\circ} \mathrm{N}\right)$ is the third largest city in Pakistan and a major industrial center, thus its air quality is an eminent environmental concern. It has an area of $1230 \mathrm{~km}^{2}$ and is inhabited by over four million people. Figure 1 shows major industries in the proximity of the sampling sites (SL), including

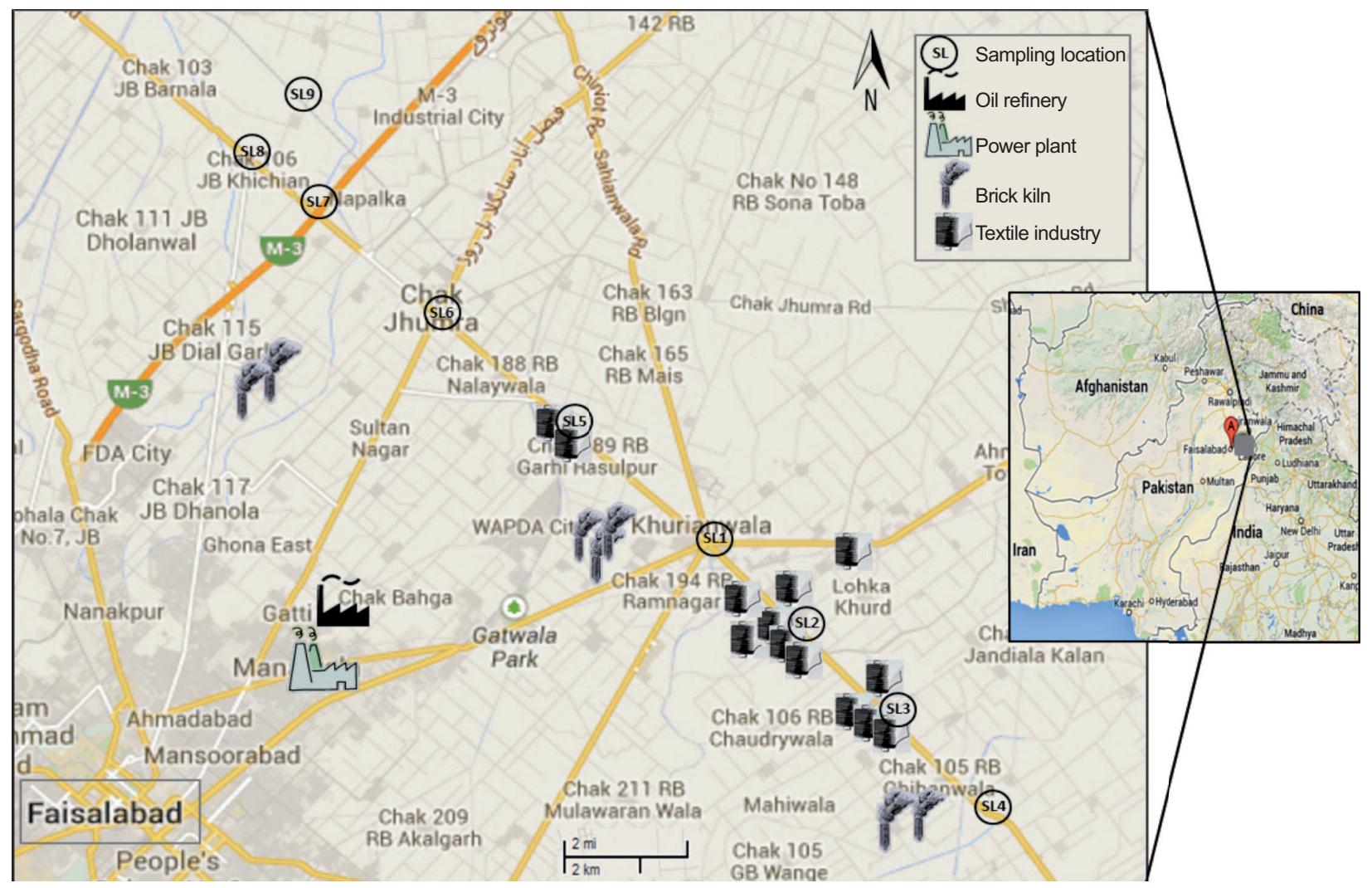

Fig. 1. Location of sampling sites and possible emission sources in the study area. The northeast corner is $39.450^{\circ} \mathrm{N}$, $21.380^{\circ} \mathrm{E}$, and the southwest corner is $23.885^{\circ} \mathrm{N}, 02.855^{\circ} \mathrm{E}$. 
textile mills, brick kilns, a power plant, and a refinery. Other major industries include marble factories, flourmills, chemical and soap factories, engineering complexes, and food processing units. Also there are eight intercity highways that are heavily trafficked. This heavy industry along with heavy traffic is a main source of air pollution in the area. The climate is characterized as hot and dry (arid) with an annual mean rainfall of $350 \mathrm{~mm}$, of which approximately $70 \%$ falls during the monsoon season (July-September). The climate is divided into four distinct seasons; hot and rainy summer (June-August) followed by autumn (September-November), cold and dry winter (December-February) and a mild spring (MarchMay). Mean maximum and minimum temperatures in summer are about $40{ }^{\circ} \mathrm{C}$ and $27{ }^{\circ} \mathrm{C}$ and in winter about $21^{\circ} \mathrm{C}$ and $6{ }^{\circ} \mathrm{C}$, respectively. The predominant wind directions are mostly from the southwest. The average $\mathrm{RH}$ in winter and summer ranges from 67 to $85 \%$ and 57 to $78 \%$, respectively. The mean $\mathrm{RH}$ in the rainy (monsoon) season is ranged from 60 to $88 \%$.

\subsection{Sampling sites}

The selection of multiple sampling sites was based on the existing anthropogenic activities responsible for air pollution, and the prevailing wind direction for pollutant distribution and dispersion in the area. Nine different sampling sites were selected to represent different urban, industrial and rural settings located downwind, to the North and East of the city center, as shown in Figure 1. Table I presents sampling sites details. Three vehicular sites (SL1, SL6, SL7) are located near road intersections $(10 \mathrm{~m})$ while six industrial and rural sites are located far away from nearby roads.

\subsection{Monitoring and sampling procedure}

Ambient PM of different size fractions (TSP, $\mathrm{PM}_{10}$, $\mathrm{PM}_{4}, \mathrm{PM}_{2.5}$ ) was monitored with a MicroDust Pro Real Time Aerosol Monitor (model HB3275-07, Casella CEL, UK) on a 6-h average basis at each sampling site. This instrument has a detection range of $0.001-2500 \mathrm{mg} \mathrm{m}^{-3}$ with a resolution $0.001 \mathrm{mg} \mathrm{m}^{-3}$.

Table I. Description of the sampling locations of the study.

\begin{tabular}{|c|c|c|c|c|c|c|c|}
\hline \multirow[t]{2}{*}{ No. } & \multirow[t]{2}{*}{ Sampling location } & \multirow{2}{*}{$\begin{array}{c}\text { Location } \\
\text { designation }\end{array}$} & \multicolumn{2}{|c|}{ Coordinates } & \multirow{2}{*}{$\begin{array}{l}\text { Elevation } \\
\text { (masl) }\end{array}$} & \multirow[t]{2}{*}{ Category } & \multirow{2}{*}{$\begin{array}{l}\text { Human } \\
\text { activities }\end{array}$} \\
\hline & & & $\mathrm{N}$ & $\mathrm{E}$ & & & \\
\hline 1 & $\begin{array}{l}\text { Khurianwala } \\
\text { intersection }\end{array}$ & SL1 & $31,29.858$ & $073,16.396$ & 187 & $\begin{array}{l}\text { Vehicular/ } \\
\text { commercial }\end{array}$ & Heavy traffic \\
\hline 2 & $\begin{array}{l}\text { Industrial cluster-1 } \\
\text { (near Ali, Kamal, } \\
\text { Rasheed textiles) }\end{array}$ & SL2 & $31,28.624$ & $073,17.778$ & 189 & $\begin{array}{l}\text { Industrial/ } \\
\text { vehicular }\end{array}$ & $\begin{array}{l}\text { Textile industries, } \\
\text { Heavy traffic }\end{array}$ \\
\hline 3 & $\begin{array}{l}\text { Industrial cluster-2 } \\
\text { (Fatima, Kamran, } \\
\text { A.I., MSC textiles) }\end{array}$ & SL3 & $31,27.039$ & $073,18.438$ & 189 & $\begin{array}{l}\text { Industrial/ } \\
\text { vehicular }\end{array}$ & $\begin{array}{l}\text { Textile industries, } \\
\text { Heavy traffic }\end{array}$ \\
\hline 4 & $\begin{array}{l}\text { Chibanwala } \\
\text { (near Chak 102RB) }\end{array}$ & SL4 & $31,23.988$ & $073,22.974$ & 190 & Rural & Brick kilns \\
\hline 5 & $\begin{array}{l}\text { Industrial cluster-3 } \\
\text { (Bismallah textile) }\end{array}$ & SL5 & $31,30.947$ & $073,14.946$ & 176 & Industrial & $\begin{array}{l}\text { Textile industries, } \\
\text { Light traffic }\end{array}$ \\
\hline 6 & $\begin{array}{l}\text { Chak Jhumra } \\
\text { intersection }\end{array}$ & SL6 & $31,33.863$ & $073,11.068$ & 164 & $\begin{array}{l}\text { Vehicular/ } \\
\text { commercial }\end{array}$ & Heavy traffic \\
\hline 7 & $\begin{array}{l}\text { M3 Motorway } \\
\text { Intersection }\end{array}$ & SL7 & $31,35.674$ & $073,08.794$ & 176 & $\begin{array}{l}\text { Vehicular/ } \\
\text { rural }\end{array}$ & Heavy traffic \\
\hline 8 & Khichian & SL8 & $31,36.675$ & $073,07.416$ & 182 & Rural & Light traffic \\
\hline 9 & Remote rural area & SL9 & $31,38.298$ & $073,07.781$ & 187 & $\begin{array}{l}\text { Background } \\
\text { rural }\end{array}$ & No local activities \\
\hline
\end{tabular}


A polyurethane foam (PUF) filter adapter with a flow rate of $3.5 \mathrm{~L} \mathrm{~min}^{-1}$ was used for size-selective monitoring of PM masses. The PUF filter loaded into the adapter determined the size of the PM being monitored. Filters are available for $\mathrm{PM}_{10}, \mathrm{PM}_{4}$, and $\mathrm{PM}_{2.5}$ size fractions. TSP mass samples were collected on micro glass fiber filter papers $(47 \mathrm{~mm})$ using a portable air sampler (model CF-1001BRL, Hi-Q, USA) fitted with a filter holder (model CFPH-25). The sampler flow rate was $5.097 \mathrm{~m}^{3} \mathrm{~h}^{-1}$ with manual compensation for increased pressure drop across the filter as it loads. Sampler and monitor were located $5 \mathrm{~m}$ above the ground level.

The PM monitoring and sampling period was spread over all four seasons; summer (June), monsoon (September), winter (January) and spring (April), spanning from June 2012 to April 2013. On sampling days, two 6-h samples were collected from 7:00 am to $1: 00 \mathrm{pm}$ and from 1:00 pm to 7:00 pm (June, 2012); 8:00 am to $2: 00 \mathrm{pm}$ and 2:00 pm to $8: 00 \mathrm{pm}$ September, 2012; April, 2013); and finally 9:00 am to 3:00 pm, and 3:00 pm to 9:00 pm (January, 2013). In all, $144(16 \times 9)$ TSP samples were collected over four sampling periods, two sampling days per nine sites per four months. Sampling was conducted simultaneously at three industrial sites (SL2, SL3, SL5), three vehicular sites (SL1, SL6, SL7) and three rural/remote sites (SL4, SL8, SL9). In addition 36 $(4 \times 9)$ field blanks were collected. The sampling periods were elected on the middle month of each season and the sampling days wholly represented the characteristics of that season. Sampling/monitoring was not performed on rainy and dust storm days.

TSP mass was also determined gravimetrically from the filters after conditioning in a desiccator for $24 \mathrm{~h}$ at $45 \pm 5 \% \mathrm{RH}$ and $23 \pm 3{ }^{\circ} \mathrm{C}$. The filter papers containing PM were stored in sealed plastic envelopes, refrigerated and transported promptly to the lab for analysis.

\subsection{Meteorological determination}

Simultaneous measurements of surface meteorological parameters such as $\mathrm{RH}$, temperature, wind speed and direction, and solar radiation were carried out with the help of a portable weather station (model 110-WS-18, Nova Lynx, USA) at each sampling site during the sampling hours. The weather station was equipped with different sensors: an anemometer for wind speed (with $0.35 \mathrm{~m} \mathrm{~s}^{-1}$ threshold and
$>0.04 \mathrm{~m} \mathrm{~s}^{-1}$ resolution) and wind direction (with 0.5 $\mathrm{m} \mathrm{s}^{-1}$ threshold and $>1 \%$ resolution); a thermo-hygrometric sensor for air temperature (with $0.05 \mathrm{C}^{\mathrm{o}}$ resolution) and $\mathrm{RH}$ (with $0.1 \%$ resolution), and a silicon pyranometer for solar radiation (with $80 \mathrm{mV}$ $/ 1000 \mathrm{w} \mathrm{m}^{-2}$ sensitivity). The data for sunshine, pan evaporation and rainfall parameters were obtained daily from the Meteorology Cell of the Crop Physiology Department, University of Agriculture, Faisalabad, Pakistan.

\subsection{Chemical analysis of PM samples}

After gravimetric analysis, each filter was cut into two equal parts. One half was used for determining trace metals after digestion in a mixture of nitric acid (Suprapure, 65\% GR grade, Merck) and perchloric acid (Suprapure, $70 \%$ GR grade, Merck) $(10: 1, \mathrm{v} / \mathrm{v})$ facilitated by heating (method IO-3.1, US-EPA, 1999). The extracted solution was filtered and diluted to $100 \mathrm{ml}$ with double distilled water and kept in refrigeration in a cleaned polyethylene bottle until analyzed. The same procedure was carried out for filter and reagent blanks. Filter and reagent blank concentrations were always less than $10 \%$ of the loaded filter values. Selected trace metals were determined by atomic absorption spectrophotometry (AAS) (Thermo AA, Solar-Series) following the method IO-3.2, US-EPA (1999). Prior to the analysis of samples, the AAS response was calibrated using a reagent blank solution and standard solutions at six different concentration levels; also, a series of continuing calibration checks were performed during the analysis of each set of samples and the extracted solution samples were run on AAS in triplicate to minimize errors.

The other filter half was used for determining water-soluble ions; five cations $\left(\mathrm{Ca}^{2+}, \mathrm{Mg}^{2+}, \mathrm{Na}^{+}, \mathrm{K}^{+}\right.$, $\left.\mathrm{NH}_{4}^{+}\right)$and three anions $\left(\mathrm{Cl}^{-}, \mathrm{SO}_{4}{ }^{2-}\right.$ and $\left.\mathrm{NO}_{3}{ }^{-}\right)$were determined after extraction in double distilled water by ultrasonication for $2 \mathrm{~h}$ (Chakraborty and Gupta, 2010). Ionic species were analyzed by ion chromatography (IC Vario-940 Metrohom, Switzerland). Peak areas were calibrated by analyzing a series of standards over the range $0.025-10 \mathrm{mg} \mathrm{L}^{-1}$.

\subsection{Quality assurance}

The US-EPA procedures/guidelines for ambient air quality monitoring (which were followed for monitoring/sampling and laboratory analysis) were counter-checked at suitable intervals. The aerosol monitor 
and high volume air sampler were daily calibrated. For TSP sampling and analysis field blanks, filter paper blanks and reagent blanks were also used to minimize errors. Laboratory testing was conducted in a manner that ensured precision and accuracy at all stages. All chemicals and solvents used were of analytical reagent grade provided by Merck (Darmstadt, Germany). Double distilled water was used in the present study. The atomic absorption spectrophotometer was standardized with a series of standard solutions supplied by the manufacturer (Thermo Electron S series; Thermo Scientific, Waltham, Mass). The reproducibility test that determines the stability of instruments exhibited a relative standard deviation of $97-101 \%$ with an average relative deviation of $<5 \%$. Inter-laboratory comparison of the AAS results was also performed at an independent laboratory (Hi-tech Laboratory, University of Agriculture, Faisalabad), and a maximum deviation of $\pm 5 \%$ was normally recorded in the results of both laboratories.

\section{Results and discussion}

3.1. Aerosol particulate matter (PM) concentrations Real-time monitoring over the measured TSP mass concentrations was performed and compared to the gravimetric method using a filter-based air sampler, as shown in Figure 2. The values are very well correlated and a maximum deviation of $10 \%$ was observed between the two methods for determining

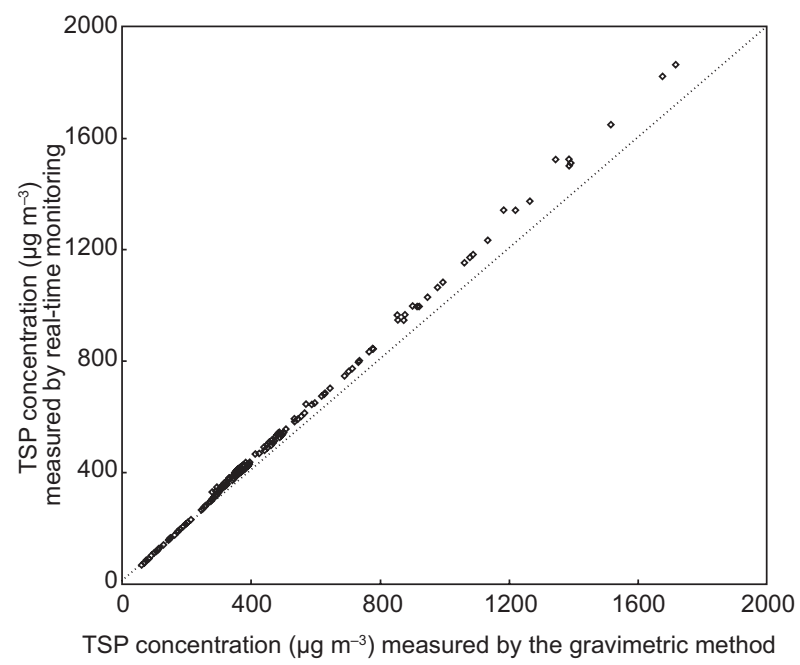

Fig. 2. Correlation between TSP mass concentrations $\left(\mu \mathrm{g} \mathrm{m}^{-3}\right)$ measured with a real time monitor and by the gravimetric method during the whole study period.
TSP mass. Spatial and temporal mass concentrations of aerosol PM during the whole study period (June 2012-April 2013) are presented in Figure 3. Overall, ambient PM concentrations far exceed the 24-h standard limits established by US-EPA (2012), WHO (2005) and Pak-EPA (2012).

Two-way analysis of variance (ANOVA) was used to test whether the temporal variations in PM mass concentration were correlated - all of the sampling sites were significantly different from each other $(\mathrm{p}<0.01)$. The highest annual average PM concentrations for all particle sizes (TSP, $\mathrm{PM}_{10}, \mathrm{PM}_{4}$ and $\mathrm{PM}_{2.5}$ ) were observed at SL2 (an industrial site) followed in decreasing order by SL3, SL1, SL4, SL6, and the lowest concentrations were recorded at a remote rural site (SL9). Similar spatial patterns were also observed during the four sampling periods within the study area, as shown in Figure 3. TSP concentrations were 2 to 16 and 1.2 to 8 times higher than the WHO $\left(120 \mu \mathrm{g} \mathrm{m}^{-3}\right)$ and US-EPA $\left(260 \mu \mathrm{g} \mathrm{m}^{-3}\right)$ 24-h standard limits, respectively, except for the background rural site (SL9). Similarly, $\mathrm{PM}_{10}$ and $\mathrm{PM}_{2.5}$ levels were 2 to 22 and 1.2 to 7 times higher than the WHO limits (50 and $25 \mu \mathrm{g} \mathrm{m}^{-3}$ ) and 1.6 to 19 and 1.2 to 13 times higher than US-EPA (150 and $35 \mu \mathrm{g} \mathrm{m}^{-3}$ ) 24-h standards, respectively, at all sites within the study area.

The highest concentrations were observed at industrial sites SL2 and SL3, proximal to a power plant, and textile, plastic, rubber and chemical industries. These sites are also located near narrow, unpaved, rough roads with heavy traffic emissions that are trapped in the narrow street canyons. The on-road vehicular fleet mainly consists of heavy-duty diesel vehicles, especially trucks, tractor-trailers, vans and local buses.

A power plant and an oil refinery located near and upwind of these sampling sites might also contribute to PM mass concentrations. Hence, emissions from industries and automobiles were the major sources of $\mathrm{PM}$ at these sites during the sampling period (Ashraf et al., 2013; Mohammed and Namuduri, 2013; Ni et al., 2013).

High PM concentrations were also observed at vehicular sites SL1 and SL6, which are major road intersections with dense traffic 24 hours per day and busy commercial districts. Traffic is congested due to the high density of heavy vehicles and the narrowing of available roadway resulting from encroachment 


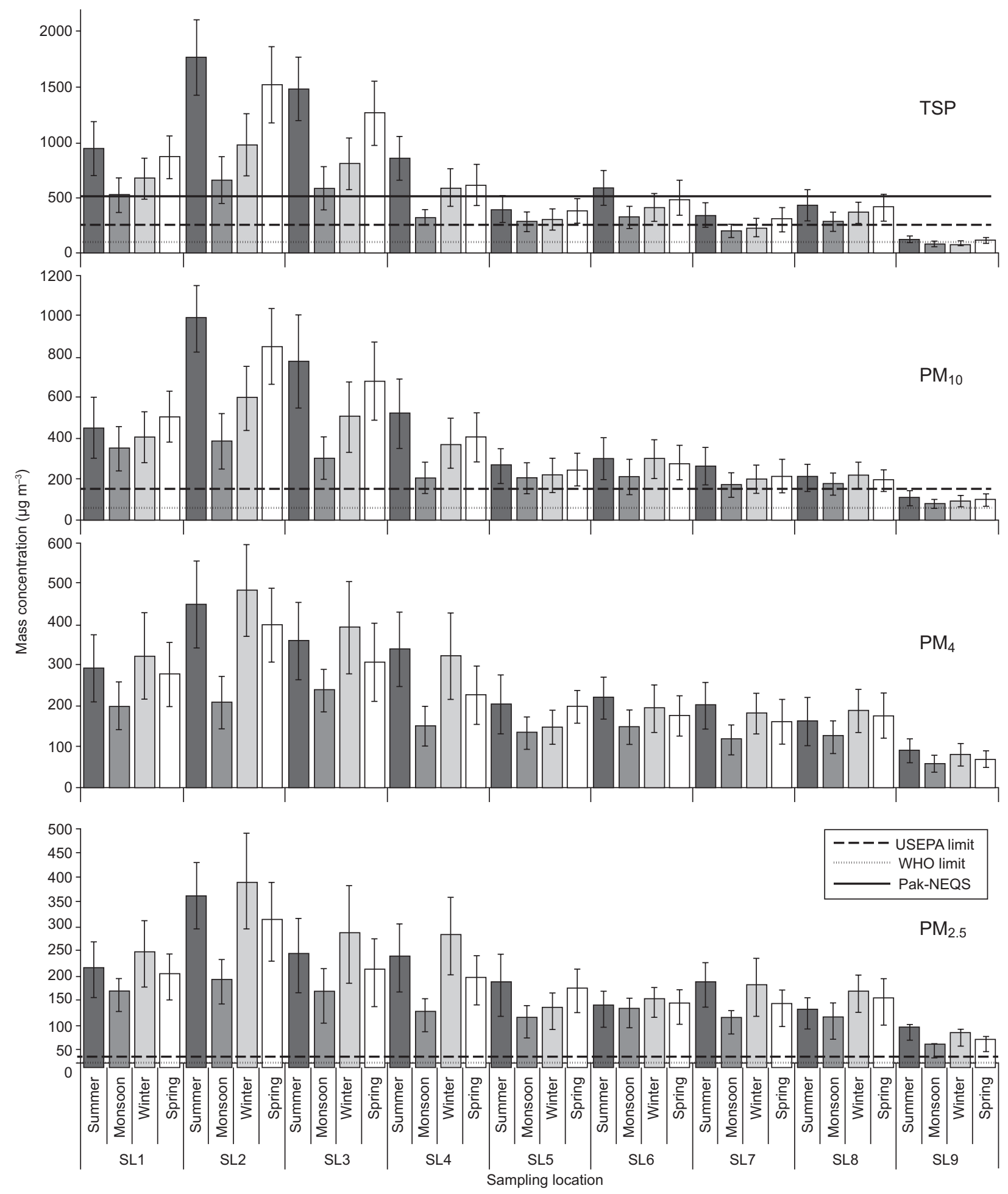

Fig. 3. Spatio-temporal mass distribution of different size fractions of aerosol PM in the study area. Horizontal lines indicate the 24-h standard limits established by US-EPA, WHO and Pak-EPA. US-EPA and Pak-NEQS have the same limits for $\mathrm{PM}_{10}$ and $\mathrm{PM}_{2.5}$. 
by merchants on both sides of the road. Roads are poorly maintained, unpaved and dusty with limited vegetation along the sides. Vehicles are typically old, poorly maintained, overloaded, smoky, employing inefficient engines that use poor quality fuel (Colbeck et al., 2010; Shah et al., 2012; Ashraf et al., 2013). Contribution to PM at these sites during the whole sampling period was mainly due to re-suspended road dust and emissions from public and commercial transportation (i.e., buses, trucks, vans, auto-rickshaws and two-wheelers). High PM mass concentrations at SL4 (a rural site) were possibly due to combustion of low quality fuel currently being used in two brick kilns located at this sampling location. Low quality coal, wood, used rubber tires and waste oil are mostly used for fuel in these kilns located within the study area (Javed et al., 2015).

On the contrary, the lowest PM concentration was recorded at a remote rural site (SL9) because the sorrounding area (up to $15 \mathrm{~km}^{2}$ ) had no vehicular and industrial activities throughout the sampling period. Vegetation is more prevalent and ventilation is better. So this location served as a background site for comparison with more polluted areas.

\subsection{Temporal distribution of PM over the study area} The average TSP concentration was significantly higher $\left(773 \pm 240 \mu \mathrm{g} \mathrm{m}^{-3}\right)$ in summer followed by spring $\left(666 \pm 230 \mu \mathrm{g} \mathrm{m}^{-3}\right)$ and winter $(505 \pm 210 \mu \mathrm{g}$ $\left.\mathrm{m}^{-3}\right)$, and its minimum $\left(365 \pm 190 \mu \mathrm{g} \mathrm{m}^{-3}\right)$ was found during the monsoon sampling period (Fig. 4). A similar pattern was observed in the case of $\mathrm{PM}_{10}$ and $\mathrm{PM}_{4}$ mass concentrations - highest during summer

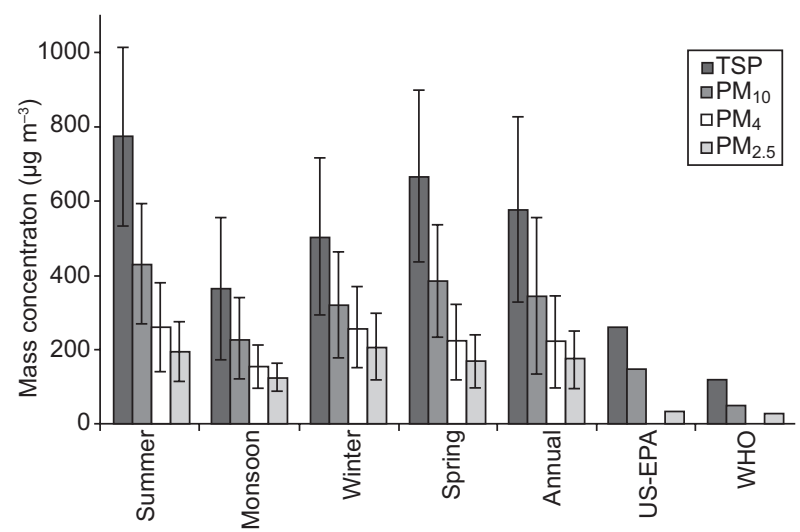

Fig. 4. Aerosol PM size distribution and mass concentration $\left(\mu \mathrm{g} \mathrm{m}^{-3}\right)$ during the study period along with $24-\mathrm{h}$ standard limits proposed by WHO and US-EPA. and lowest during the monsoon sampling period. In contrast, the $\mathrm{PM}_{2.5}$ average concentration was highest $\left(209 \pm 90 \mu \mathrm{g} \mathrm{m}^{-3}\right)$ during winter and lowest (124 $\pm 40 \mu \mathrm{g} \mathrm{m}^{-3}$ ) during the monsoon sampling period. This high $\mathrm{PM}_{2.5}$ concentration during the winter period can be attributed to lower temperature and wind speed that result in reduced atmospheric mixing coupled with higher anthropogenic activities such as biomass burning and space heating (Karar et al., 2006; Chakraborty and Gupta, 2010; Pakbin et al., 2010; Ni et al., 2013). That is why visibility in Faisalabad and its surrounding areas during foggy winter days is often as low as $50 \mathrm{~m}$. The lower PM concentrations observed during the monsoon sampling period can be attributed to wash-out by rainfall, wet surfaces and higher $\mathrm{RH}$ that reduces re-suspension of road and crustal dust (Budhavant et al., 2009; Celo and Dabek-Zlotorzynska, 2010; Shah et al., 2012), but also to the shutdown of brick kilns. Higher concentrations of coarse particles (TSP, $\mathrm{PM}_{10}$ and $\mathrm{PM}_{4}$ ) were found during the summer sampling period likely due to the enhanced re-suspension of road and crustal dust favored by higher temperature and wind speed, coupled with lower rainfall and RH (Pakbin et al., 2010; Shah and Shaheen, 2010). Also, a few dust storms were observed during the summer sampling period. In addition, local brick kilns operate during the dry seasons while most are closed during the wet season. On the whole, it is observed that PM pollution in ambient air of different areas of Faisalabad, especially those having high vehicular and

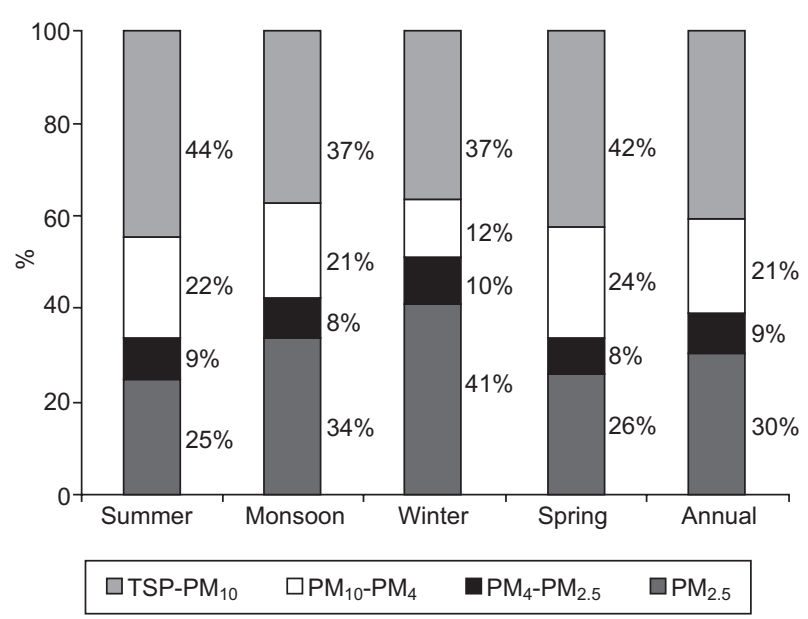

Fig. 5. Percentage (\%) of aerosol PM size distribution during the study period. 
industrial activities, has become a serious problem and it is more severe during dry periods.

\subsection{Aerosol PM size fractionation}

Figure 5 shows the size distribution of PM within the study area. The TSP-PM $\mathrm{P}_{4}$ fraction is about $62 \%$ of the average TSP mass, whereas $\mathrm{PM}_{2.5}$ is about $30 \%$. The $\mathrm{PM}_{2.5}$ mass is about $52 \%$ of $\mathrm{PM}_{10}$, indicating that the dominant sources in the study area are anthropogenic processes. During summer and spring the coarse fraction contributes to a larger portion of the average TSP mass (66\%) indicating that mechanical processes (i.e., re-suspension of road/crustal dust, stone crushing/cutting, constructions activities, etc.) are the most likely sources (Karar et al., 2006). In addition, a box and whisker plot (Fig. 6) also depicts that coarse PM fractions (TSP, $\mathrm{PM}_{10}$ and $\mathrm{PM}_{4}$ ) are not as normally distributed as fine fractions $\left(\mathrm{PM}_{2.5}\right)$, since in the former mean and median are dissimilar whereas in the latter they have nearly the same value. During the winter sampling period $\mathrm{PM}_{2.5}$ constitutes an overwhelming fraction (41\%) of PM, thereby indicating the presence of enhanced anthropogenic activities, favorable conditions for the accumulation of fine particles (which have higher residence time in air), and more combustion activities from space heating (Karar et al., 2006; Cheung et al., 2011; Alolayan et al., 2013; Yu et al., 2013).

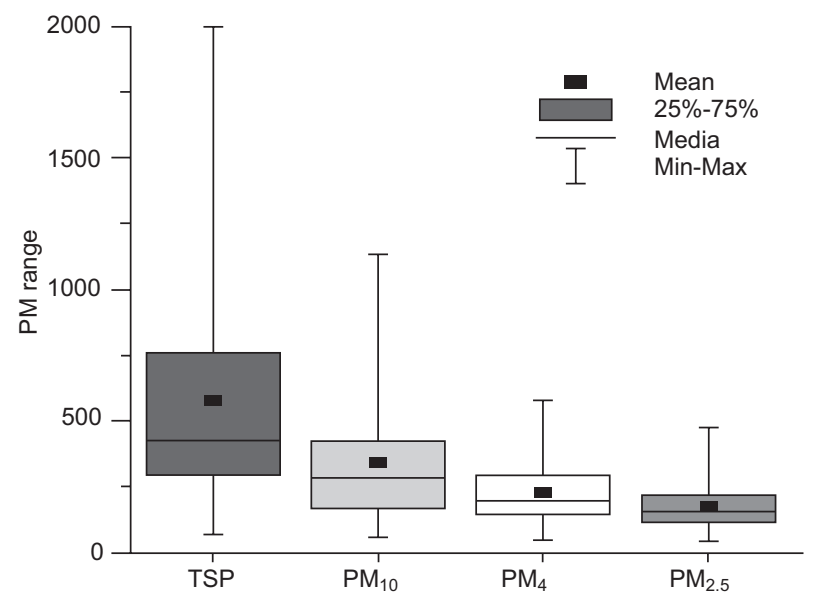

Fig. 6. Box and whisker plot showing airborne PM distribution patterns for the study period.

\subsection{Aerosol chemical species}

The spatial and temporal variations in trace metal and ion concentrations were tested by two-way ANOVA.
Figures 7-9 illustrate that all sampling periods and sites were significantly different from each other $(p<0.01)$ regarding trace metals and ions concentrations. Chemical species concentrations followed nearly the same spatial pattern as PM mass concentrations - highest at the industrialized SL2 and SL3 sites, followed by traffic congested SL1 and SL6, and lowest at the remote rural site (SL9).

The crustal metal Fe was found to be present in higher concentrations as compared to other metals. Higher levels of $\mathrm{Zn}$ and $\mathrm{Cu}$ were also observed during the summer and spring sampling periods because these metals, which are mostly emitted from lubricant oil, brake linings, and tire wear of poorly maintained and old vehicles plying on the roads (Shah et al., 2012; Alolayan et al., 2013), are also associated with paved road dust. Among the cations, $\mathrm{Ca}^{2+}, \mathrm{Mg}^{2+}, \mathrm{Na}^{+}$ and $\mathrm{K}^{+}$also exhibited higher concentrations during the summer (Fig. 8), since these ions are mostly associated with a crustal origin (Cheung et al., 2011; Alolayan et al., 2013). A similar trend was also found for the $\mathrm{Cl}^{-}$anion. Higher concentrations of these elements during the summer period were likely due to higher wind speed and temperature, and dry conditions that resulted in enhanced re-suspension of crustal/road dust (Pakbin et al., 2010; Shah and Shaheen 2010; Ni et al., 2013).

Trace metals of anthropogenic origin, such as $\mathrm{Pb}, \mathrm{Cd}$, and $\mathrm{N}$, presented relatively lower concentrations. These metal concentrations were likely due to anthropogenic emissions (e.g., vehicles, industries, coal and oil combustion, etc.), so maxima were found at locations characterized by nearby intensive industrial and vehicular activities (Mijic et al., 2012). Higher concentrations of these metals were found during the winter period likely due to increased anthropogenic activities as well as prevailing cool and calm meteorological conditions that resulted in reduced mixing-layer height and dispersion conditions that favor accumulation of these metals in the atmosphere (Chakraborty and Gupta, 2010; Yu et al., 2013). In Pakistan, $\mathrm{Pb}$ is still being used as an anti-knock agent for gasoline despite a ban on leaded fuel, because compliance is not yet enforced. Also, $\mathrm{Pb}$ has become part of the road dust due to the use of leaded fuel over the years (Chakraborty and Gupta, 2010; Colbeck et al., 2010). Nickel also exhibits similar trends to that of $\mathrm{Pb}$, with higher levels during the winter 


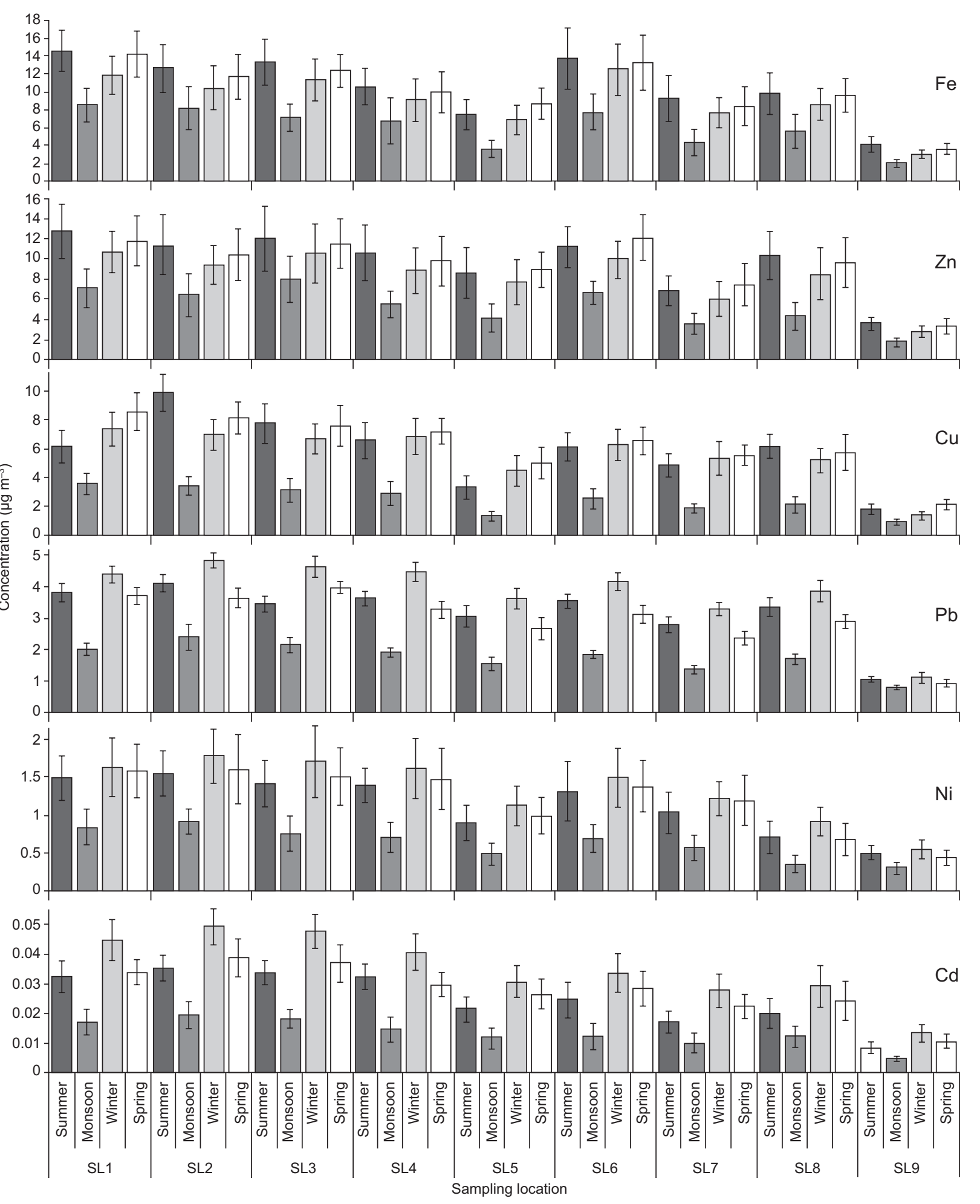

Fig. 7. Spatio-temporal distribution of TSP-associated trace metals in the study area. 


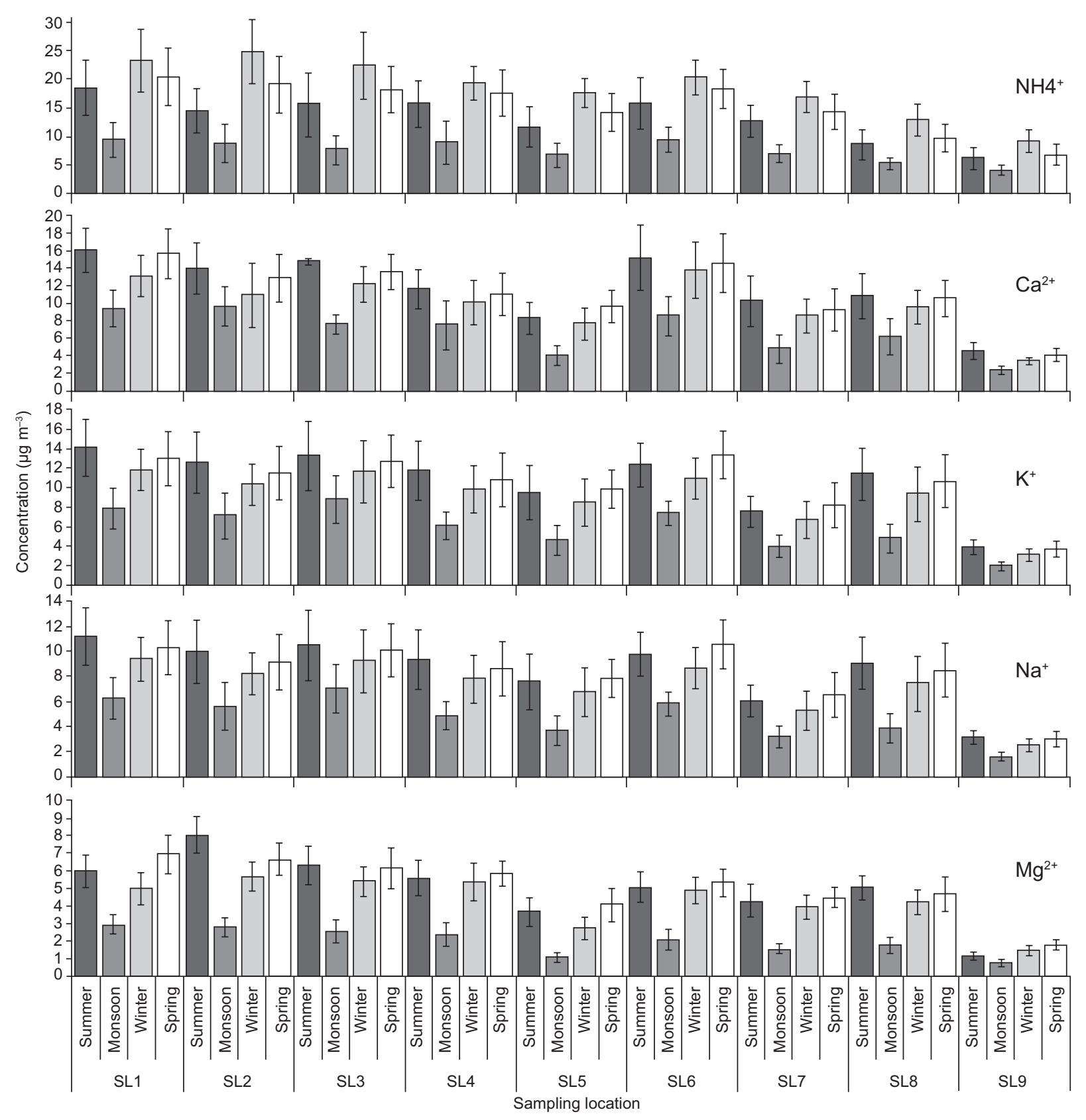

Fig. 8. Spatio-temporal distribution of TSP-associated water-soluble cations in the study area.

sampling period. The likely Ni source was crude oil combustion in a power plant and an oil refinery located near and upwind of the sampling sites (Mijic et al., 2012; Yu et al., 2013). Use of low quality coal, wood, used rubber tires and waste oil as fuel in brick kilns located within the study area was also a likely source of trace metals such as $\mathrm{Cd}, \mathrm{Zn}, \mathrm{Cu}$ and $\mathrm{Pb}$ (Celo and Dabek-Zlotorzynska, 2010; Shah et al., 2012).
$\mathrm{K}^{+}$and $\mathrm{Cl}^{-}$ions are mostly emitted by coal, biomass and waste burning (Yu et al., 2013), and they are also associated with a crustal origin. As Faisalabad is an inland city, marine impacts on aerosol PM can be ignored. Higher $\mathrm{K}^{+}$and $\mathrm{Cl}^{-}$concentrations during summer and spring periods should be due to burning of wheat-straw, sugarcane-trash and cornstalk after harvest (Shen et al., 2009). Non-crustal $\mathrm{K}$ has been used as an indicator of biomass burning emissions (Shen et al., 2007) and 

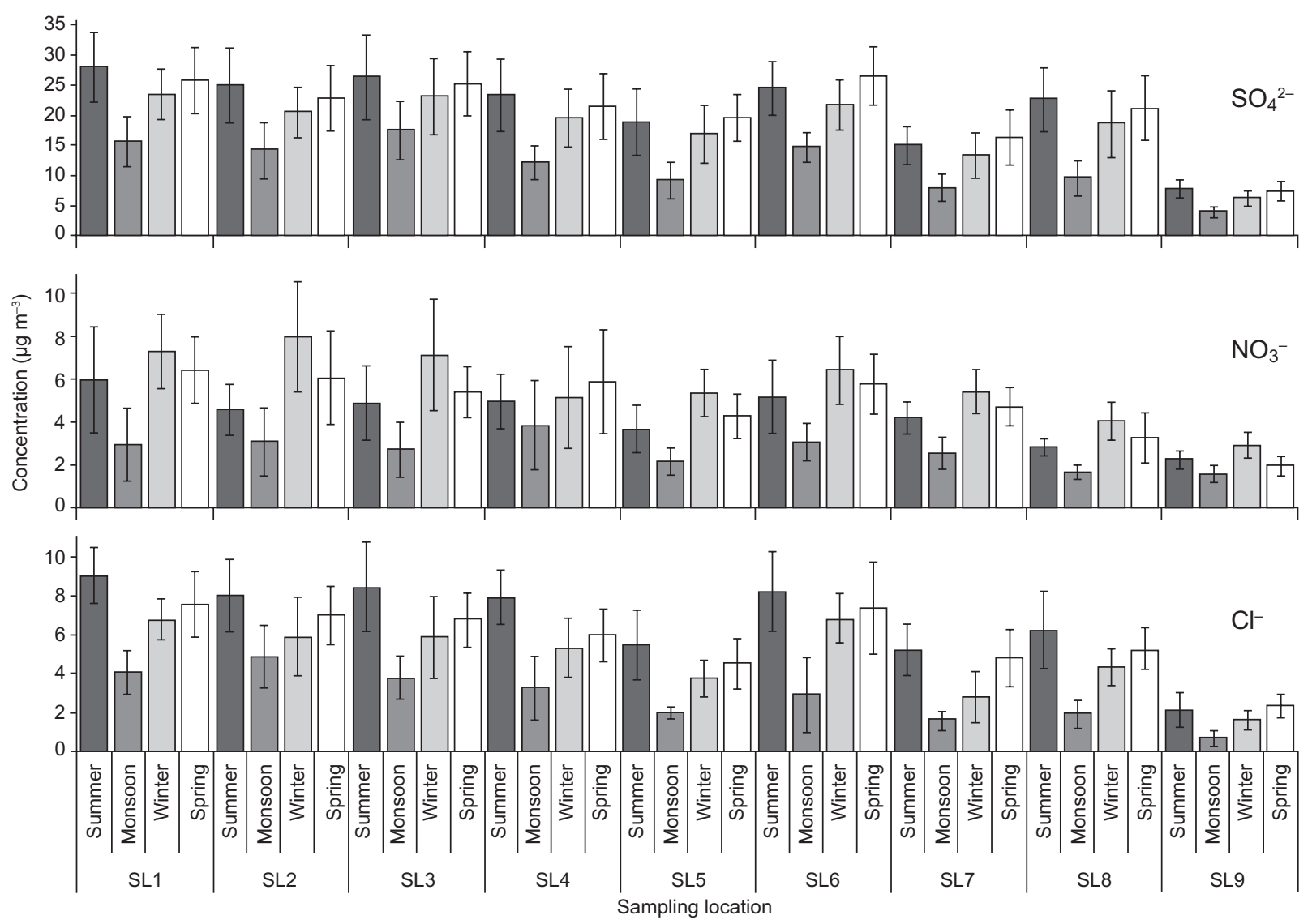

Fig. 9. Spatio-temporal distribution of TSP-associated water-soluble anions in the study area.

could be separated from crustal sources by using an approach described by Miranda et al. (1994) as non-soil $\mathrm{K}=\mathrm{K}-0.52 \mathrm{Fe}$, by applying a $\mathrm{K} / \mathrm{Fe}$ ratio $(0.52)$ of coarse soil. From the total average $\mathrm{K}\left(6.02 \mu \mathrm{g} \mathrm{m}^{-3}\right)$, $1.84 \mu \mathrm{g} \mathrm{m}^{-3}$ are contributed by biomass burning and the remaining fraction $\left(4.18 \mu \mathrm{g} \mathrm{m}^{-3}\right)$ is associated with crustal origin.

Among the water-soluble anions, sulfate $\left(\mathrm{SO}_{4}{ }^{2-}\right)$ was the predominant species, contributing with $50-60 \%$ of the total anion concentration, as found previously by Chakraborty and Gupta (2010). Both $\mathrm{SO}_{4}{ }^{2-}$ and $\mathrm{NO}_{3}{ }^{-}$anions, as well as the $\mathrm{NH}_{4}{ }^{+}$cation exhibited highest concentrations during winter and lowest during the monsoon sampling period (Figs. 8, 9). This can be attributed to lower temperature, higher $\mathrm{RH}$ and calm conditions with lower mixing height during the winter period, which favored accumulation of these ions in the atmosphere, as well as increased anthropogenic activities such as biomass burning and space heating (Cheung et al., 2011; Alolayan et al., 2013; Ni et al., 2013). All measured chemical species were lowest during the monsoon sampling period when high $\mathrm{RH}$ and wet surfaces minimized the re-suspension of crustal/road dust and wash-out by rainfall (Budhavant et al., 2009; Chakraborty and Gupta, 2010; Yu et al., 2013).

It was found that the $\mathrm{NO}_{3}^{-}$concentration in $\mathrm{PM}$ is lower than the $\mathrm{SO}_{4}{ }^{2-}$ concentration. Essentially, nitrate cannot exist in the particle phase unless its acidity is near neutral. In these observations, nitrate was almost invariably observed, which indicates excess of ammonia in the atmosphere that neutralizes the particulate sulfate and condenses with the nitrate forming the particulates ammonium sulfate $\left(\left(\mathrm{NH}_{4}\right)_{2} \mathrm{SO}_{4}\right)$ and ammonium nitrate $\left(\mathrm{NH}_{4} \mathrm{NO}_{3}\right)(\mathrm{Han}$ et al., 2008; Shen et al., 2009; Chakraborty and Gupta 2010). In contrast, higher summer temperatures increase dissociation of $\mathrm{NH}_{4} \mathrm{NO}_{3}$ to form the gases nitric acid and ammonia (Alolayan et al., 2013).

\subsection{Aerosol ionic balance}

Ionic balance (as mole equivalents) can be a useful 
Table II. Ion balance (neq $\mathrm{m}^{-3}$ ) of PM samples from the study area.

\begin{tabular}{|c|c|c|}
\hline Ionic species & $\begin{array}{c}\text { Mean } \\
\text { concentration } \\
\left(\mathrm{ng} \mathrm{m}^{-3}\right)\end{array}$ & $\begin{array}{l}\text { Equivalent } \\
\text { charge } \\
\left(\text { neq } \mathrm{m}^{-3}\right)\end{array}$ \\
\hline $\mathrm{Mg}^{2+}$ & 3190 & 261 \\
\hline $\mathrm{Ca}^{2+}$ & 8040 & 400 \\
\hline $\mathrm{Na}^{+}$ & 6160 & 268 \\
\hline $\mathrm{K}^{+}$ & 6020 & 154 \\
\hline $\mathrm{NH}_{4}^{+}$ & 11170 & 621 \\
\hline $\mathrm{SO}_{4}{ }^{2-}$ & 16480 & 343 \\
\hline $\mathrm{NO}_{3}^{-}$ & 7480 & 121 \\
\hline $\mathrm{Cl}^{-}$ & 6120 & 172 \\
\hline Eanions & & 636 \\
\hline Ecations & & 1704 \\
\hline ¿anions $/ \Sigma$ cations & & 0.373 \\
\hline Anions deficiency & & 1068 \\
\hline
\end{tabular}

tool to determine any possible missing ionic species, so this method was applied to PM from the study area (Table II). The results of $\Sigma$ anions $/ \Sigma$ cations for PM were well below one unit, which shows that there is a quite reasonable anion deficiency in PM, thus suggesting that positive charges from cations are not totally neutralized by negative charges from anions (Mkoma et al., 2014). The apparent anion deficiency shows that PM samples are, in fact, alkaline. This buffering of acidity by the PM is certainly due to high mineral dust loadings. If this is the case, $\mathrm{CO}_{3}{ }^{2-}$ is a prominent alkaline component of dust precursor materials and is expected to associate with $\mathrm{Ca}^{2+}$ in the coarse PM fraction (Shen et al., 2007, 2009). In the present study, most anions $\left(\mathrm{F}^{-}, \mathrm{Br}^{-}, \mathrm{I}^{-}, \mathrm{PO}_{4}{ }^{2-}, \mathrm{S}^{2-}\right.$, $\mathrm{SiO}_{3}{ }^{2-}, \mathrm{CO}_{3}{ }^{2-}, \mathrm{HCO}_{3}^{-}$etc.) and other organic anions $\left(\mathrm{CH}_{3} \mathrm{COO}^{-}, \mathrm{HCOO}^{-}, \mathrm{C}_{2} \mathrm{O}_{2}^{-}, \mathrm{C}_{2} \mathrm{O}_{4}{ }^{2-}\right.$ etc. $)$ were not measured in $\mathrm{PM}$ samples because the greatest portion (80\%) of the chemically analyzed TSP mass remained unidentified, so there is a huge ionic imbalance in ion concentrations as found earlier by Mkoma et al. (2015).

\subsection{Correlation analysis \\ 3.6.1 PM mass correlation with meteorological parameters}

Table III shows that TSP mass was strongly correlated with $\mathrm{PM}_{10}$ and $\mathrm{PM}_{4}$ fractions, with $r^{2}$ values of 0.78 and 0.65 , respectively. This suggested that these fractions have a significant contribution to the overall TSP mass. The similarly finer fractions $\mathrm{PM}_{4}$ and $\mathrm{PM}_{2.5}$ exhibited a closer mutual relationship with an $r^{2}$ value as high as 0.88 . Thereby, coarse and fine fractions of PM appeared to have an independent behavior, in agreement with the earlier paradigm that abrasive processes emit coarse material and combustion-oriented processes emit ultrafine material that grows by condensation into the fine mode.

A negative correlation was observed between $\mathrm{RH}$ and the coarse fractions TSP and $\mathrm{PM}_{10}$ while there is a positive correlation with the relative fine fractions $\mathrm{PM}_{4}$ and $\mathrm{PM}_{2.5}$. Fine particle mass $\left(\mathrm{PM}_{2.5}\right)$ was also negatively correlated with temperature, which confirms that lower temperature favors accumulation and condensation to particles in this size range. On the other hand, high temperature increases dissociation

Table III. Pearson correlation coefficient matrix for PM size fractions and meteorological parameters during the study period $(\mathrm{n}=144)$.

\begin{tabular}{lcccccccccc}
\hline & TSP & PM10 & PM4 & PM2.5 & WS & RH & Temp & PE & SR & SS \\
\hline PM10 & $0.78^{*}$ & & & & & & & & & \\
PM4 & $0.65^{*}$ & $0.46^{*}$ & & & & & & & & \\
PM2.5 & $0.43^{*}$ & $0.65^{*}$ & $0.88^{*}$ & & & & & & & \\
WS & $0.69^{*}$ & $0.52^{*}$ & $-0.65^{*}$ & $-0.74^{*}$ & & & & & & \\
RH & $-0.72^{*}$ & $-0.62^{*}$ & $0.45^{*}$ & $0.85^{*}$ & $-0.70^{*}$ & & & & & \\
Temp & 0.39 & 0.37 & 0.25 & $-0.42^{*}$ & 0.32 & $-0.74^{*}$ & & & & \\
PE & 0.23 & 0.28 & 0.24 & 0.32 & $0.80^{*}$ & $-0.82^{*}$ & $0.78^{*}$ & & & \\
SR & $0.46^{*}$ & $0.56^{*}$ & $0.68^{*}$ & $0.62^{*}$ & 0.37 & $-0.58^{*}$ & $0.53^{*}$ & $0.84^{*}$ & & \\
SS & 0.17 & 0.19 & 0.36 & 0.38 & 0.25 & $-0.72^{*}$ & $0.75^{*}$ & $0.89^{*}$ & $0.85^{*}$ & \\
RF & $-0.76^{*}$ & $-0.72^{*}$ & $-0.82^{*}$ & $-0.87^{*}$ & $0.46^{*}$ & $0.83^{*}$ & -0.30 & -0.26 & $-0.51^{*}$ & $-0.42 *$ \\
\hline
\end{tabular}

*Significant at $p<0.01$ (two-tailed $t$-test); RH: relative humidity; RF: rainfall; SR: solar radiation; SS: sunshine; PE: pan-evaporation; WS: wind speed. 
of fine particles (Alolayan et al., 2013). Rainfall, as accepted, was found to have a negative effect over all size fractions of PM due to its scavenging effect (Karar et al., 2006; Budhavant et al., 2009), especially during the monsoon sampling period (September), when $202 \mathrm{~mm}$ of rainfall were collected in nine days. Solar radiation was found to positively affect the $\mathrm{PM}$ mass, notably $\mathrm{PM}_{4}$ and $\mathrm{PM}_{2.5}$, since an increased actinic flux leads to formation of condensable inorganic and organic compounds. Sunshine and pan evaporation turned out to be non-significant parameters for PM concentrations. Wind speed was also found to affect positively the coarse fractions, likely due to the suspension of dust, and negatively the fine fractions, likely due to the dust scavenging condensable inorganic and organic compounds that would have condensed on the fine fraction (Pakbin et al., 2010; Mohammed and Namuduri, 2013). As strong winds (1.11-3.59 $\mathrm{m} \mathrm{s}^{-1}$ ) were encountered during the summer sampling period, a corresponding temporal distribution of PM provided support to this effect of meteorology.

\subsubsection{Correlation of TSP chemical species with me- teorological parameters}

Table IV shows both positive and negative correlations between species concentrations and meteorological parameters. Crustal elements $\mathrm{Fe}, \mathrm{Mg}, \mathrm{Ca}$ and $\mathrm{Na}$ were positively correlated with wind speed, confirming that these particles were emitted due to windblown road and crustal dust in the sampling area. Thereby, these elements have a negative relationship with RH. In contrast, metals of anthropogenic origin $\mathrm{Zn}, \mathrm{Cu}, \mathrm{Pb}$, and $\mathrm{Ni}$ and ions $\left(\mathrm{SO}_{4}{ }^{2-}, \mathrm{NO}_{3}{ }^{-}\right.$and $\left.\mathrm{NH}_{4}{ }^{+}\right)$ were negatively correlated with the wind speed possibly due to increased dispersion (Mohammed and Namuduri, 2013). These ions are also negatively correlated with temperature and positively correlated with RH; as discussed earlier, lower temperature and higher humidity favored condensation of semi-volatile species (Karar et al., 2006; Cheung et al., 2011; Alolayan et al., 2013). It was also found that, as expected, rainfall had a negative and pivotal role on all chemical species, indicating its scavenging effect as was the case of PM mass concentrations (Budhavant et al., 2009; Yu et al., 2013). Solar radiation, sunshine and pan evaporation parameters were observed to have mostly a positive correlation with all chemical species.

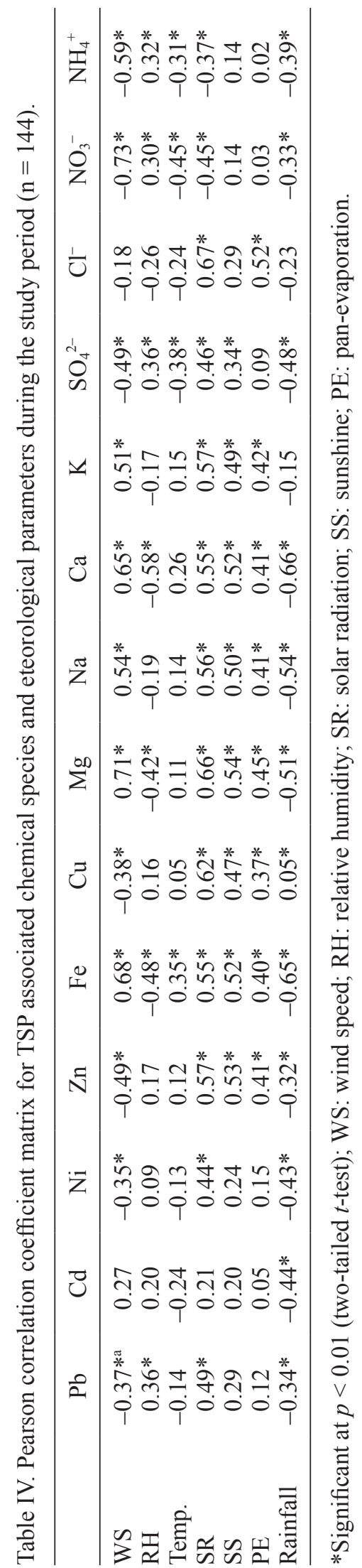




\subsubsection{PM mass correlation with TSP chemical spe- cies}

The chemical species concentrations showed intermediate to strong correlations with particle sizes, as reported in Table V. In the spectrum of all correlations, crustal elements (i.e., $\mathrm{Fe}, \mathrm{Mg}, \mathrm{Ca}$ and $\mathrm{Na}$ ) were found to be strongly associated with coarse size fractions (TSP and $\mathrm{PM}_{10}$ ) and the elements of anthropogenic origin $(\mathrm{Cd}, \mathrm{Pb}, \mathrm{Ni}, \mathrm{Zn}$ and $\mathrm{Cu})$ were strongly associated with fine size fractions $\left(\mathrm{PM}_{2.5}\right)$ (Ni et al., 2013; Yu et al., 2013). Uniquely, Zn, K and $\mathrm{Na}$ exhibited strong to intermediate correlations with all particle size fractions suggesting that these might be derived from both crustal/road dust and anthropogenic origin. In particular, $\mathrm{Zn}$ is emitted by multiple sources, such as vehicle emissions, tire wear, diesel soot, oil industries and coal combustion (Xia and Gao, 2011). Secondary anions $\left(\mathrm{SO}_{4}{ }^{2-}\right.$ and $\left.\mathrm{NO}_{3}^{-}\right), \mathrm{Cl}^{-}$and one cation $\left(\mathrm{NH}_{4}^{+}\right)$also turned out to be strongly associated with fine fractions, thereby suggesting that these ions reside in fine particles. These correlation findings duly supported previous assertions in this section regarding spatial and temporal distributions of these species.

\subsubsection{Correlation among TSP chemical species}

In Table VI the correlation coefficients with $r$ values significant at $p<0.01$ show some significant mutual correlations between relevant pairs of elements in terms of their concentrations. Apparently, elements that are strongly correlated indicate some common sources (Shah and Shaheen, 2010).

Hence, a strong correlation between $\mathrm{Pb}$ and $\mathrm{Cd}$ with $r=0.89$ suggests a common source of these elements. Further, it could be noted that $\mathrm{Pb}$ also significantly correlates to $\mathrm{Zn}, \mathrm{Cu}$ and $\mathrm{Ni}$ with $r$ values of $0.74,0.73,0.71$ and 0.60 , respectively. Similarly, $\mathrm{Cd}, \mathrm{Zn}, \mathrm{Cu}$ and $\mathrm{Ni}$ are strongly correlated. So this group of elements $(\mathrm{Pb}-\mathrm{Cd}-\mathrm{Zn}-\mathrm{Cu}-\mathrm{Ni})$ that have strong mutual correlations mainly emanates from industrial as well as vehicular emissions (Xia and Gao, 2011). A strong correlation was also found for $\mathrm{Fe}-\mathrm{Ca}(r=0.82), \mathrm{Fe}-\mathrm{Mg}(r=0.81)$ and $\mathrm{Mg}-\mathrm{Ca}$ $(r=0.80)$, indicating a common source for these elements - the Earth's crust (Balakrishna and Pervez, 2009). Some less significant correlations were also observed for $\mathrm{Zn}-\mathrm{Mg}$, $\mathrm{Zn}-\mathrm{Fe}, \mathrm{Zn}-\mathrm{Na}, \mathrm{Mg}-\mathrm{Cu}$ and $\mathrm{Mg}-\mathrm{Na}$, suggesting that this group is emitted by re-suspended soil and road dust (Pakbin et al., 2010; 


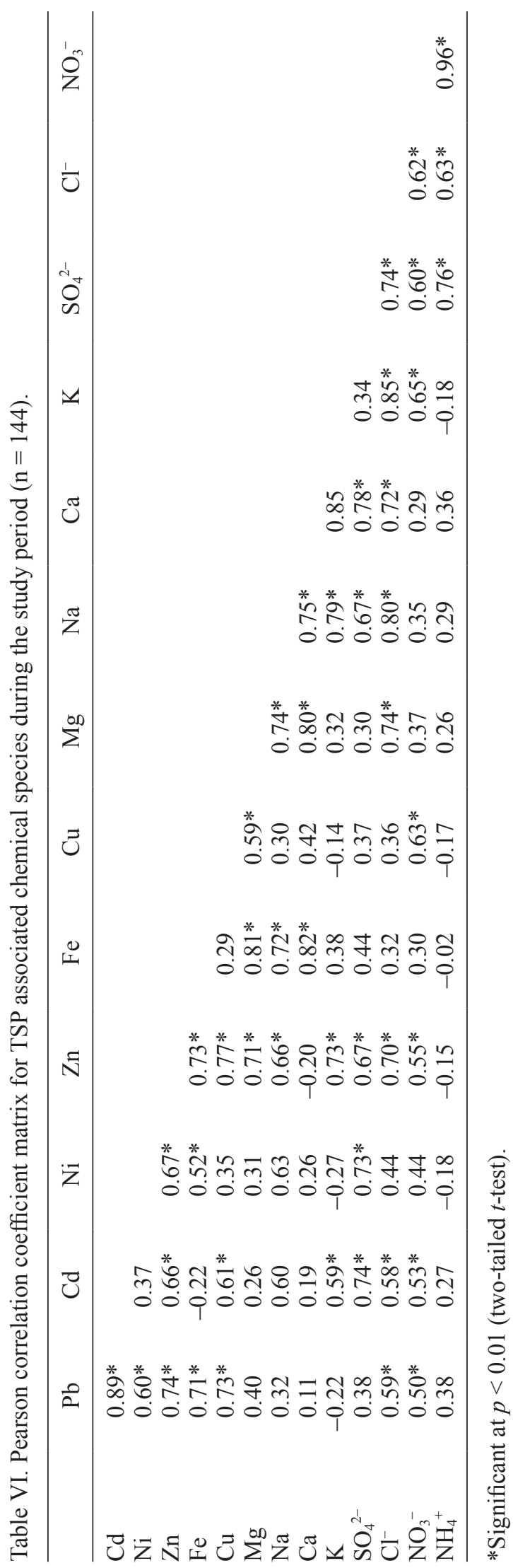

Ni et al., 2013). Another significantly associated group is $\mathrm{K}-\mathrm{Cl}-\mathrm{Na}-\mathrm{Ca}-\mathrm{Mg}$, which is mainly originated from coal and biomass burning (Shen et al., 2009; Yu et al., 2013). Similarly, ions like $\mathrm{SO}_{4}{ }^{2-}, \mathrm{NO}_{3}{ }^{-}$and $\mathrm{NH}_{4}^{+}$are strongly correlated, indicating their common origin as secondary particle compounds in the atmosphere (Shen et al., 2007, 2009; Cheung et al., 2011). Noted irregular and inconsistent correlation patterns suggested that these elements possibly originate from several sporadic local sources that are described and applied in a companion paper (Javed et al., 2015).

\section{Conclusions}

The present study showed a significant spatial and temporal variation of mass concentrations of different PM size fractions and its chemical constituents in the local atmosphere of Faisalabad, mainly due to changes in anthropogenic activities and prevailing meteorological conditions. The highest PM concentrations were observed at industrial sites, followed by busy road intersections, as compared to a background site. Coarse particles (TSP, $\mathrm{PM}_{10}$ and $\mathrm{PM}_{4}$ ) were found to be highest during the summer sampling period and fine particles $\left(\mathrm{PM}_{2.5}\right)$ during the winter period, while concentrations of all size fractions were lowest during the monsoon sampling period. The temporal concentrations of different elements and water-soluble ions showed trends similar to PM mass concentrations - relatively lower during the monsoon and higher during the summer and winter sampling periods. The major elements in the local atmosphere $(\mathrm{Ca}, \mathrm{Fe}, \mathrm{Mg}$ and $\mathrm{Na}$ ) were of crustal origin while elements of anthropogenic origin $\mathrm{Pb}, \mathrm{Cd}, \mathrm{Ni}, \mathrm{Cu}$ and $\mathrm{Zn}$ emerged as minor contributors. Anion concentrations were highest during winter. Among anions, sulfate was the predominant species contributing to $50-60 \%$ of the total anion concentration. Correlation results showed that rainfall, wind speed and $\mathrm{RH}$ were the most important meteorological factors affecting the concentration of measured pollutants.

\section{Acknowledgments}

This study was funded by the Higher Education Commission, Government of Pakistan. It is part of a Ph.D. research work by the corresponding author, who would like to thank Prof. (Ret.) Dr. Abdul Ghafoor for his guidance regarding the research plan, 
as well as personnel from the Air Quality Research Center, UC Davis, for writing assistance.

\section{References}

Alolayan M. A., K. W. Brown, J. S. Evans, W. S. Bouhamra and P. Koutrakis, 2013. Source apportionment of fine particles in Kuwait City. Sci. Total Environ. 448, 14-25.

Ashraf N., M. Mushtaq, B. Sultana, M. Iqbal, I. Ullah and S. A. Shahid, 2013. Preliminary monitoring of tropospheric air quality of Lahore City in Pakistan. Int. J. Chem. Biochem. Sci. 3, 19-28.

Balakrishna G. and S. Pervez, 2009. Source apportionment of atmospheric dust fallout in an urban-industrial environment in India. Aerosol Air Qual. Res. 9, 359-367.

Becker S., L. A. Dailey, J. M. Soukup, S. C. Grambow, R. B. Devlin and Y. C. T. Huang, 2005. Seasonal variations in air pollution particle-induced inflammatory mediator release and oxidative stress. Environ. Health Persp. 113, 1032-1038.

Bhaskar B. V., R. V. J. Rajasekhar, P. Muthusubramanian and A. P. Kesarkar, 2008. Measurement and modeling of respirable particulate $\left(\mathrm{PM}_{10}\right)$ and lead pollution over Madurai, India. Air Qual. Atmos. Health. 1, 45-55

Budhavant K. B., P. S. P. Rao, P. D. Safai and K. Ali, 2009. Chemistry of monsoon and post-monsoon rains at a high altitude location, Sinhabad, India. Aerosol Air Qual. Res. 9, 65-79.

Celo V. and E. Dabek-Zlotorzynska, 2010. Concentration and source origin of trace metals in $\mathrm{PM}_{2.5}$ collected at selected Canadian sites within the Canadian National Air Pollution Surveillance Program. In: Urban airborne particulate matter. Environmental science and engineering (F. Zereini and C. L. S. Wiseman, Eds.). Springer, Heidelberg, 19-38.

Chakraborty A. and T. Gupta, 2010. Chemical characterization and source apportionment of submicron $\left(\mathrm{PM}_{1}\right)$ aerosol in Kanpur region, India. Aerosol Air Qual. Res. 10, 433-445.

Cheung K., N. Daher, W. Kam, M. M. Shafer, Z. Ning, J. J. Schauer and C. Sioutas, 2011. Spatial and temporal variation of chemical composition and mass closure of ambient coarse particulate matter $\left(\mathrm{PM}_{10-2.5}\right)$ in the Los Angeles area. Atmos. Environ. 45, 2651-2662.

Colbeck I., Z. A. Nasir, S. Ahmad and Z. Ali, 2010. The state of ambient air quality in Pakistan - a review. Environ. Sci. Pollut. Res. 17, 49-63.

Han Y. J., S. K. Tae and H. Kim, 2008. Ionic constituents and source analysis of $\mathrm{PM}_{2.5}$ in three Korean cities. Atmos. Environ. 42, 4735-4746.
Javed W., A. S. Wexler, G. Murtaza, Y. Zhao, H. R. Ahmad and M. M. Iqbal, 2015. Chemical characterization and source apportionment of total suspended particulate matter in Faisalabad, Pakistan. J. Environ. Sci. (submitted).

Karar K., A. K. Gupta, A. Kumar and A. K. Biswas, 2006. Characterization and identification of the sources of chromium, zinc, lead, cadmium, nickel, manganese and iron in $\mathrm{PM}_{10}$ particulates at the two sites of Kolkata, India. Environ. Monit. Assess. 120, 347-360.

Mar T. F., T. V. Larson, R. A. Stier, C. Claiborn and J. Q. Koenig, 2004. An analysis of the association between respiratory symptoms in subjects with asthma and daily air pollution in Spokane, Washington. Inhal. Toxicol. 16, 809-815.

Mijic Z., A. Stojic, M. Perisic, S. Rajsic and M. Tasic, 2012. Receptor modeling studies for the characterization of $\mathrm{PM}_{10}$ pollution sources in Belgrade. Chem. Ind. Chem. Eng. Q. 18, 623-634.

Miranda J., T. A. Cahill, J. R. Morales, F. Aldape, J. Flores and R. V. Díaz, 1994. Determination of elemental concentrations in atmospheric aerosols in Mexico-City using proton-induced x-ray-emission, proton elastic-scattering, and laser-absorption. Atmos. Environ. 28, 2299-2306.

Mkoma S. L., G. O. Rocha, J. S. Domingos, J. V. Santos, M. P. Cardoso, R. L. Silva and J. B. Andrade, 2014. Atmospheric particle dry deposition of major ions to the South Atlantic coastal area observed at Baía de Todos os Santos, Brazil. An. Acad. Bras. Cienc. 86, 37-55.

Mohammed M. P. and S. Namuduri, 2013. Trace elemental composition in the atmospheric aerosols of Kakinada city, India. Sustain. Environ. Res. 23, 315-324

Ni T., P. Li, B. Han, Z. Bai, X. Ding, Q. Wang, J. Huo and B. Lu, 2013. Spatial and Temporal Variation of Chemical Composition and Mass Closure of Ambient $\mathrm{PM}_{10}$ in Tianjin, China. Aerosol Air Qual. Res. 13, 1832-1846

Pakbin P., N. Hudda, K. L. Cheung, K. F. Moore and C. Sioutas, 2010. Spatial and temporal variability of coarse $\left(\mathrm{PM}_{10-2.5}\right)$ particulate matter concentrations in the Los Angeles area. Aerosol Sci. Technol. 44, 514-525,

Pak-EPA/JICA, 2001. Three cities investigation of air and water quality (Lahore, Rawalpindi \& Islamabad). Pakistan Environmental Protection Agency/Japan International Cooperation Agency, June. Available at. http://www.environment.gov.pk/pub-pdf/3city-inv.pdf (last accessed on July 3, 2008).

Pak-EPA, 2005. State of the environment report. Pakistan Environmental Protection Agency, Ministry of Environment, Government of Pakistan. 
Pak-EPA, 2012. The National Environmental Quality Standards (NEQS) for air. Pakistan Environmental Protection Agency, Ministry of Environment, Government of Pakistan.

Pope III C. A., 2000. Review: Epidemiological basis for particulate air pollution health standards. Aerosol Sci. Technol. 32, 4-14.

Ragosta M., R. Caggiano, M. Macchiato, S. Sabia, and S. Trippetta, 2008. Trace elements in daily collected aerosol: level characterization and source identification in a four-year study. Atmos. Res. 89, 206-217

Shah M. H. and N. Shaheen, 2010. Seasonal behaviors in elemental composition of atmospheric aerosols collected in Islamabad, Pakistan. Atmos. Res. 95, 210-223.

Shah M. H., N. Shaheen and R. Nazir, 2012. Assessment of the trace elements level in urban atmospheric particulate matter and source apportionment in Islamabad, Pakistan. Atmos. Pollut. Res. 3, 39-45.

Shen Z. X., J. J. Cao, R. Arimoto, R. J. Zhang, D. M. Jie, S. X. Liu and C. S. Zhu, 2007. Chemical composition and source characterization of spring aerosol over Horqin sand land in northeastern China. J. Geophys. Res. 112, D14315, doi:10.1029/2006JD007991.

Shen Z., J. Cao, Z. Tong, S. Liu, L. S. S. Reddy, Y. Han, T. Zang and J. Zhou, 2009. Chemical characteristics of submicron particles in winter in Xi'an. Aerosol Air Qual. Res. 9, 80-93.

US-EPA, 1999. Selection, preparation and extraction of filter material. In: Compendium of methods for the determination of inorganic compounds in ambient air.
Method IO-3.1. United States Environmental Protection Agency, Cincinnati, OH, USA.

US-EPA, 1999. Determination of metals in ambient particulate matter using Atomic Absorption (AA) spectroscopy. In: Compendium of methods for the determination of inorganic compounds in ambient air. Method IO3.2. United States Environmental Protection Agency, Cincinnati, OH, USA.

US-EPA, 2012. Revised air quality standards for particle pollution and updates to the Air Quality Index (AQI). United States Environmental Protection Agency, Office of Air Quality Planning and Standards, EPA 454/ R99-010. Available at: http://www.epa.gov/pm/2012/ decfsstandards.pdf.

WHO, 2005. WHO Air Quality Guidelines Global Update 2005 - Particulate matter, ozone, nitrogen dioxide and sulphur dioxide. World Health Organization, Regional Office for Europe, Copenhagen. Available at: http:// www.euro.who.int/Document/E90038.pdf.

World Bank, 2006. Pakistan: Strategic country environment assessment, vol. II, report No. 36946-PK. World Bank, Washington.

Xia L. and Y. Gao, 2011. Characterization of trace elements in $\mathrm{PM}_{2.5}$ aerosols in the vicinity of highways in northeast New Jersey in the U.S. East Coast. Atmos. Pollut. Res. 2, 34-44.

Yu L., G. Wang, R. Zhang, L. Zhang, Y. Song, B. Wu, X. Li. K. An and J. Chu, 2013. Characterization and source apportionment of $\mathrm{PM}_{2.5}$ in an urban environment in Beijing. Aerosol Air Qual. Res. 13, 574-583. 